\title{
Food Composition of the Metad, Rattus meltada pallidior in Western Rajasthan
}

\author{
SKEAD POKARMU RATTUS MELTADA PALLIDIOR
}

\author{
B. D. RANA \& Ranjan ADVANI
}

\begin{abstract}
Rana B. D. \& Advani R., 1981: Food composition of the metad, Rattus meltada pallidior in Western Rajasthan. Acta theriol., 26, 7: 129-132 [With 1 Table].

Seasonal fluctuations in the stomach contents of the Soft-furred field rat, Rattus meltada pallidior (Ryley, 1914), collected from rangelands and crop fields at Bisalpur, India, reveal that it is primarily a herbivore. It consumes 87.7 to 99.7 per cent plant parts of which the majority is constituted by wheat on an annual basis. It also feeds upon insects all the year, round, though in low proportions. Inclusion of wheat in the diet, particularly during the season when the crop is absent from the field, suggests that the field rats enter the nearby godowns to feed upon their preferred food. This involvs shifting of their natural habitat, from grasslands to croplands and then to foodgrain stores.
\end{abstract}

[Central Arid Zone Res. Inst., Jodhpur - 342003, India]

\section{INTRODUCTION}

The soft-furred field rat, Rattus meltada pallidior (Ryley, 1914) is fairly distributed throughout India. This metad causes severe losses to both rain-fed (Kharif) as well as irrigated (Rabi) crops (Rana \& Prakash, 1980) which are of considerable economic importance in the Indian agriculture. Very little is known about the feeding habits of this field rat which is found in abundance in the crop fields. In this paper we present the results of our studies on the stomach-contents analyses of this rodent.

\section{STUDY AREA}

This study was conducted in the crop fields and rangeland at Bisalpur $\left(25^{\circ} 7^{\prime} \mathrm{N}\right.$; $\left.73^{\circ} 10^{\prime} \mathrm{E}\right), 10 \mathrm{kms}$ far from Erinpura. It falls under region receiving annual rainfall of $500 \mathrm{~mm}$, and aridity index being - 73. The main crops grown in the study area are - wheat (Triticum aestivum), cotton (Gosypium hirsutum), maize (Zea mays), jowar (Sorghum bicolor), barley (Hordeum vulgare), castor (Ricinus communis) and pulse moong (Vigna radiatus). The native vegetation cover in the rangeland is composed of Dichanthium annulatum, Eremopogon faveolatus, Heteropogon contortus, Cenchrus setigerus and Cymbopogon martinii.

\section{METHODS}

The metads were collected every month from January to December, 1978 from a double crop field. Soon after collection, the rodents were weighed, sexed and dissected. The contents of stomach were spread on a sheet of paper and dried at room temperature. Food items of all the rodents captured in a month were mixed and treated as a monthly sample. Later on, different food items were sorted out and identified. Each food item was measured gravimetrically following (Murton et al., 1964) on a semi-micro mettler balance. Frequency of occurrence 
of each food item has been expressed as per cent of the total sample collected during a month. The total number of metads (N) collected and examined in each month are shown in parenthesis in the Table 1. ?

\section{RESULTS}

\section{Food on Annual Basis}

Rattus meltada chiefly thrives upon wheat plant parts and grains which constitute about 63.3 per cent of the total food. The other important food item which featured in the stomach contents is the seeds of a fodder grass, Dichanthium annulatum (27.54 per cent). Insect diet was mainly composed of Coleoptera, Hymenoptera, Dermaptera and Hemiptera.

\section{Seasonal Variations}

Winter season (December to February): During this season wheat grains, stem and leaves constitute the bulk of their stomach contents. The other important food was cotton fibres. During this period ripe cotton capsules are available to the metads. They feed mainly on seeds (15.0 per cent) but possibly some cotton fibres are also swallowed.

Summer season (March to June): During March and April wheat featured at the rate of 96.3 per cent and 99.6 per cent respectively. However, during May, it fed mainly on seeds of Dichanthium annulatum, 58.6 per cent. A low proportion of cotton seeds and fibres also occur in the stomach contents which suggests that either they are picked up by the rodents from the field where they are sown or from the godowns. The maximum occurrence of insects (Table 1) during June may be explained by the fact that in the absence of other native vegetation they switch over to more nutritious and watery diet.

Monsoon season (July to September): During monsoon the frequency of occurrence of wheat grains decreased to its lowest level and that of grasses reached its peak. The presence of its own fur, indicates the increase in social interactions among the population. A meagre proportion of insects was also eaten. Cotton fibres occur in appreciable quantity.

Post monsoon season (October and November): The frequency of occurrence of wheat slightly increased during this season,. whereas, cotton fibres occurred in low proportion as compared to monsoon season. Among the other food items cucurbits, seeds of brinjal, and insects also fared.

\section{DISCUSSION}

The majority of rodents inhabiting arid and semi-arid regions of the world are omnivorous, depending on both vegetation and insects at various times of the year to maintain their energetic and nutritional requirements (Reichman et al., 1979). Members of the genus Rattus generally accept a wide spectrum of foods.

This study on the food of Rattus meltada pallidior has indicated that it is primarily a herbivore, vegetation composing its annual diet at 
Table 1

Seasonal variations in the food composition of Rattus meltada pallidior.

\begin{tabular}{|c|c|c|c|c|c|c|c|c|c|c|c|c|c|}
\hline Food items & $\begin{array}{c}(30)^{1} \\
\text { Jan. }\end{array}$ & $\begin{array}{l}(27) \\
\text { Feb. }\end{array}$ & $\begin{array}{l}(22) \\
\text { Mar. }\end{array}$ & $\begin{array}{l}(17) \\
\text { Apr. }\end{array}$ & $\begin{array}{l}\text { (13) } \\
\text { May }\end{array}$ & $\begin{array}{r}\text { June } \\
(16)\end{array}$ & $\begin{array}{r}\text { July } \\
(14)\end{array}$ & $\begin{array}{l}\text { Aug. } \\
\text { (11) }\end{array}$ & $\begin{array}{c}\text { Sept. } \\
(15)\end{array}$ & $\begin{array}{l}\text { Oct. } \\
\text { (19) }\end{array}$ & $\begin{array}{l}\text { Nov. } \\
\text { (46) }\end{array}$ & $\begin{array}{l}\text { Dec. } \\
(48)\end{array}$ & $\begin{array}{c}\text { Annual } \\
\text { composition, } \\
\%\end{array}$ \\
\hline Wheat stems and leaves & 45.4 & 68.7 & 96.3 & 68.4 & 37.4 & - & - & - & - & - & 50.5 & 29.6 & 22.2 \\
\hline $\begin{array}{l}\text { Wheat grains } \\
\text { Semicrushed wheat }\end{array}$ & 0.7 & - & - & 2.1 & 0.9 & - & - & - & - & - & - & - & 0.2 \\
\hline $\begin{array}{l}\text { grains and flours } \\
\text { Cotton seeds and }\end{array}$ & 37.6 & 26.8 & - & 29.1 & 2.8 & 52.4 & 35.5 & 51.2 & 34.2 & 61.4 & 43.6 & 42.6 & 41.0 \\
\hline fibres & 15.1 & - & - & - & - & 2.04 & - & - & 15.8 & 8.5 & 4.0 & 5.3 & 4.9 \\
\hline Cucurbit seeds & - & - & - & - & - & 1.2 & - & - & 1.8 & - & 0.7 & - & 0.4 \\
\hline Grasses $^{2}$ & - & - & - & - & 58.6 & 37.7 & 57.7 & 36.5 & 43.7 & 25.8 & - & 21.8 & 27.5 \\
\hline Brinjal seeds & - & - & - & - & - & - & - & - & - & 1.0 & - & - & 0.0 \\
\hline Total vegetation & 98.7 & 95.5 & 96.3 & 99.6 & 99.8 & 93.3 & 93.2 & 87.7 & 95.6 & 96.7 & 98.8 & 99.6 & \\
\hline Fur & 0.3 & 2.6 & 2.0 & - & 0.2 & - & 6.1 & 10.7 & 2.6 & 2.2 & 0.1 & 0.2 & 2.4 \\
\hline Mammalian intestine & - & - & - & - & - & - & - & - & - & - & 0.9 & - & 0.1 \\
\hline Insects $^{3}$ & 1.04 & 1.9 & 1.7 & 0.4 & - & 6.7 & 0.6 & 1.6 & 1.8 & 1.0 & 0.1 & 0.1 & 1.4 \\
\hline
\end{tabular}

1 The total number of animals examined, ${ }^{2}$ Mainly Dichan thium annulatum, 3 Coleoptera (Scarabaeidae), Hymenoptera, Dermaptera, Hemiptera. 
a tune of 87.7 to 99.7 per cent. Insects are eaten all the year round but in a very low proportion. Another aspect which is brought to the light is that Rattus meltada feeds upon wheat grains even when the crop is not in the field which shows that they are entering the godowns, which are situated within the crop fields. This is a serious situation worthy of attention by the rodent control personnel. During this century the bandicoot, Bandicota bengalensis has almost totally replaced the house rat, Rattus rattus population in the godowns in Howrah (Calcutta) and Bombay (Spillet, 1968 and Deoras, 1966). Further to this it has been observed that Bandicota bengalensis has migrated (possibly through transport systems) to the Bikaner town (Rajasthan desert) in the grain "mandis in recent years and the species is spreading fast (Prakash \& Mathur, 1979). In Bikaner $\left(28^{\circ} 0^{\prime} \mathrm{N}, 73^{\circ} 17^{\prime} \mathrm{E}\right)$, Tatera indica population is already well established in the urban environment having partially replaced the Rattus rattus and Mus musculus population. The evidence provided by the present study that Rattus meltada pallidior, essentially a pasture rodent has now not only shifted to the crop fields but also to the grain stores is worthy of concern because still another species which inhabited the wild environment is now intruding to live with man, as a commensal, chiefly to feed upon the preferred food, wheat.

The study also indicates that the grasses are available to the metads in the field in a very large quantity but they prefer to feed on wheat, even after entering a new environment (the godowns). This habit indicates that they are selective in feeding behaviour.

Acknowledgements: Authors wish to express their gratitude towards Dr. $\mathrm{H}$. S. Mann, Director, Central Arid Zone Research Institute, Jodhpur, for encouragement and providing necessary facilities and to Dr. Ishwar Prakash, Professor of Eminence, for critically going through the communication. Thanks are also due to Dr. P. K. Ghosh, Head of Animal Studies Division for his able guidance through out the course of this study. Assistance rendered by our colleagues in the field is also duly acknowledged.

\section{REFERENCES}

Deoras P. J., 1966: Significance of probable change of rat population in Bombay. Proc. Ind. Rodent Symp., 58-68. - Murton R. K., Westwood M. J. \& Isaacson A. J., 1964: Feeding habits of the Wood pigeon, Columbia palumbus; Stockdove Columbia oenas and Turtle dove, Streptopelia turtur. Ibis, 106: 174-188. Prakash I. \& Mathur R. P., 1979: Bandicota bengalensis in Bikaner town. Rod. Newsl., 3: 12. - Rana B. D. \& Prakash I., 1980: The metad - a serious rodent pest of Indian agriculture. Ind. Farmg., 29: 21-23. - Reichman O. J., Prakash I. \& Roig V., 1979: Food selection and consumption in IBP. Arid Land Synthesis, 116: 685-716. - Spillett J. J., 1968: The ecology of the lesser bandicoot rat in Calcutta. J. Bombay nat. Hist. Soc. and Johns Hopkins Univ.: XII +1-223.

Accepted, September 20, 1980. 